\title{
Study on the Authenticity Perception of Intangible Cultural Heritage
}

\author{
Jun Hu, Xiaona Feng, Mu Zhang, Jing Luo* \\ Shenzhen Tourism College, Jinan University, Shenzhen, China \\ Email: *ivyluojing@163.com
}

How to cite this paper: $\mathrm{Hu}, \mathrm{J}$., Feng, X. N., Zhang, M., \& Luo, J. (2019). Study on the Authenticity Perception of Intangible Cultural Heritage. Current Urban Studies, 7, 35-58.

https://doi.org/10.4236/cus.2019.71003

Received: December 24, 2018

Accepted: March 11, 2019

Published: March 14, 2019

Copyright ( 2019 by author(s) and Scientific Research Publishing Inc. This work is licensed under the Creative Commons Attribution International License (CC BY 4.0).

http://creativecommons.org/licenses/by/4.0/

(c) (i) Open Access

\begin{abstract}
As a challenging topic in tourism, the authenticity of the cultural heritage represents the value and attraction of heritage. With tourism development, scholars have called for the authenticity perception of cultural heritage which still stays at the conceptual level. However, there are few researches that involve the essence and protection of authenticity. Hence, after in-depth study on the characteristics of intangible cultural heritage, the authors try to discuss the difference of tourists' perception on authenticity of the intangible cultural heritage so as to achieve the effective protection of intangible cultural heritage. The study investigates tourists in Bo Luo Dan Temple Fair with SPSS to carry on the statistics and the main factors affecting the perception of authenticity to further study their relationship with satisfaction. The conclusion found that there were two core factors that had an impact on perceived authenticity, and there exists significant positive impact between the authenticity of the perception and satisfaction.
\end{abstract}

\section{Keywords}

Intangible Cultural Heritage, Authenticity, Visitor, Perception

\section{Introduction}

In the year of 2003, UNESCO issued "the Convention for the Safeguarding of Intangible Cultural Heritage" to advocate for the worldwide concern about domestic intangible cultural heritage. With the speed procedure of economic globalization and modernization, traditional belief, value and lifestyle seem to be away from us. Though China witnesses splendid achievement since the reform in the 1980s, we have to admit the weakening impact of traditional culture on

${ }^{\star}$ Corresponding author. 
the youth. Western culture and lifestyle has gradually integrated in our life which brings threats for our traditional culture. In order to tackle this problem, the State Council made "the Notice for Further Safeguarding Intangible Cultural Heritage". And there set off an upsurge for heritage application after two successful cases for heritage application which are Kun Opera and Mongolian Long Tone, approved as the representative of Oral and Intangible Culture. Thereafter, there are 25 intangible cultural heritages such as Dragon boat festival, Rice Paper of Anhui, Huaer Tune of Gansu etc. which are ranked in this list. After two applications, there has selected 1028 intangible heritages into the index of national intangible heritage, and 4315 have been listed in provincial index of intangible heritage.

As most intangible heritages are been on the verge of extinction for little support, governments are expected to put large amount of money to guarantee its temporary existence. However, the governments cannot afford to help all the projects. Only a small part of intangible heritage has been taken good care of, because the rest of them have to fight for the survival of themselves. Under this circumstance, both scholars and enterprises have realized economic and tourism value of intangible heritage, so they proposed the necessity and possibility of industrialization of intangible heritage and tourism development. The application of intangible heritage, building of national intangible heritage parks, restoration of Folk or Temple Fair prove the commencement of intangible cultural heritage. In 2009, Ministry of Culture and China National Tourism Administration issued "The Guidance on Promoting the Development of Culture and Tourism" which suggested making full use of the resource strength of intangible cultural heritage to enhance culture status of tourism product by encouraging more cultural projects and activities. Therefore, tourism development of intangible cultural heritage tends to be the trend and a hot topic.

Being away from original environment, most intangible cultural heritages are at the risk of extinction. At present, there are 10 categories in intangible cultural heritage. They are: folk literature, folk music, folk dance, folk drama, folk painting, traditional handicraft, Chinese medication, folk art, acrobatics and folk sports. The purpose of tourism development is to seek the balance between development and protection to achieve sustainability without damages during this process. Intangible cultural heritage needs necessary publicity and adjustment, however, overpacking might extort the essence of culture which leads to the loss of its natural beauty and tourism value. Hence, it is an important issue to discuss how to safeguard the authenticity of intangible cultural heritage in tourism development. The study on tourists' perception on authenticity from intangible cultural heritage will not only provide the foundation for increasing tourists' experience, but also might offer constructive suggestions on protecting cultural essence of intangible cultural heritage.

Because few researches could be found in China, the authors choose folk in- 
tangible culture heritage of Guangdong province as the case to evaluate the differentiation of their perception to figure out the factors that affect their perception towards authenticity, and finally to conclude the relationship between authenticity perception and customer satisfaction in intangible cultural heritage tourism.

\section{Literature Review on Authenticity of Heritage and Visitors Perception}

\subsection{Intangible Cultural Heritage}

Comparing with cultural heritage, the concept of intangible cultural heritage refers to various practice, performance, exhibition, knowledge, skill, relevant tools, handicrafts, and cultural place regarded by people, group or individual, which is approved by UNESCO in Convention for the Safeguarding of the Intangible cultural Heritage (Wang, 2006).

The term authenticity originates from Greek, which indicates original, it is also known as originality or reliability. It was firstly introduced to describe the art exhibition in museum. Macannell is the first scholar to apply authenticity in the research of tourist motives and experience. The understanding of authenticity in perspective of heritage evolves with some documents In "Venice Charter" (1964), it puts forward the policy on the applicable level, for example, this document emphasizes the job of heritage protection cannot change the original layout and decoration (item 5), and the environment around it should be safeguarded too (item 6 and 7) etc. Hence, these technical measurements concerning about authenticity have been selected in "Guideline of World Heritage Convention” (1997-2002) Nara Convention (1994) offers a completed conceptual framework of authenticity by positioning it on cultural diversity. It also broadens the connotation of authenticity including "form and design, materials, function and utility location and environment and other internal and external factors". The "Guideline for Application of World Heritage Convention" makes more specific and detailed statements on authenticity (1977-2005). What's more, another concept "integrity" is introduced in heritage protection, which is defined as "the unspoiled measures and integration of nature and cultural heritage. With three implications included: firstly, it contains all the elements of universal value of heritage; secondly, there exists certain size indicating heritage characteristics and evolution. Thirdly, it could sustain the negative impact from development and ignorance.

During twenty years, there are following categories about concept and intonation of authenticity.

1) Objectivism

Objectivism views authenticity as an inborn characteristic of tourism to be measured by an absolute criterion. Boors Tin thinks tourists actually are not interested in local culture, what attracts them is the artificial and unauthentic event. McConnell, however, holds the opposite idea with Boortin in the Stage 
Authenticity Theory, the unauthenticiy in real life makes tourism pursuit authenticity during the travel. Meanwhile, he also addresses the idea that most modern tourist experience belongs to experiencing stage authenticity rather than the real culture of tourism destination. And authenticity is always described as authentic and unauthentic while analyzing national cultural heritage such as art works, festival, convention, food, costumes, house etc. according to local convention and culture (Ma, 2006).

2) Constructivism

It assumes that the authenticity mirrors tourists' belief, expectation, preference, image and awareness during the travel. Bruner clarifies the concept of constructive authenticity. That is tourism operator could design scenic spot and relative event tailoring with tourist imagination, expectation, preference and belief (Zhou et al., 2007). Hughes addresses that various channels such as tourism enterprise, marketing agent, tour guide and brochure or Vedio producer make tourism authenticity (Hughes, 1995). Under the framework of constructivism, what the tourists seek is only a semiotic and symbolic authenticity which brings by social construction.

3) Post-modernism

Postmodernism views authenticity by emphasizing heterogeneity, particularity and uniqueness and excluding integrity for postmodernism doesn't concern tourist authenticity for they pursue artificial beauty, entertainment and joy. Ritzer Liskas matters authenticity only when they doubt about un-authenticity. They reflect on the impact from tourists to vulnerable local culture. And they support the positive role of stage authenticity to protect the culture and community in the destination.

4) Existentialism

As existentialism concerns tourists, though the scenic spot is absolutely unauthentic, it is still workable to pursue it. Because tourist can find an alternative, that is, tourism experience is activated by existing authenticity, which is approved by Naoi. There are two major parts of existing authenticity, intra-personal authenticity and inter-personal authenticity, which are able to guide the development of tourism. Hence, for the above mentioned, there are different points of view and focuses on authenticity which play a role in tourism development and marketing strategies. In terms of tourism resource development, the historical cultural heritage with great demand of authenticity needs more emphasis on the prominence of its history and tradition, known as tourist' authenticity. While, those theme parks centered with entertainment should cultivate tourists' existence authenticity with satisfying tourism psychological needs. And for folk tourism resource, it is suggested to keep balance on tourism development with attaching importance on the authenticity of subject and object.

Apostolakis (2003) and Yeoman et al. (2007) think authenticity could be regarded as a guarantee for tourism supplier to indicate the compatibility of authenticity protection and market. Cohen (1988) addressed that commercial ap- 
proach could activate folk and traditional culture. While Deepar (2003) proposed the authenticity of folk culture, which was beneficial to the reconstruction of traditional culture and nationality identity. So there is no doubt that tourism economy will bring dual influence on the completeness of local economy, residents and heritage. Goulding (2000) insisted that commercialization of culture heritage would never damage its authenticity, rather, It represented its exchange value. What's more, the experience of pursuit of authenticity is seen as an important tourism tendency, Tomaz and Vesna (2009) agreed with the idea that authenticity was full of significance for tourism, especially heritage tourism, the concept of authenticity would not only help to understand tourist motivation and behavior, it also offered strategic role in the management of tourism destination. Alexandro (2003) proposed that the authenticity would play a critical role in building tourism motive and attraction. Many Chinese scholar participated the hot discussion. Gao (2008) concluded that cultural product and authenticity did not hold the opposite stance, instead, they was in the mutual-promote relationship under the setting of cultural commercialized development with case study of the show named "Yunnan Impression". Ma (2006) discussed the relationship among authenticity, commercialization, national culture heritage and tourism, it suggested if the process of tourism commercialization was dominated by the local, it was possible for the revitalization of nationality tourism and cultural tourism. Wang and Zhang (2007) found that the stakeholders would bear different understanding for heritage tourism authenticity, as there were different perception on heritage authenticity among tourist, residents and tourism operator with various needs, it was important to construct the authenticity of heritage destination in the way of guiding the authenticity mass media, building interpretation system and strengthening residents cultural identity. It is concluded that all the studies on authenticity of intangible cultural heritage starts from concept, and then people propose the philosophy of protection. But few researches could be found in the perspective of tourists' perception on authenticity of intangible cultural heritage. Therefore, the authors will study tourists' perception on authenticity combining with the characteristics of cultural heritage tourism, and then further to discuss whether authenticity perception of intangible cultural heritage works on tourists satisfaction.

\subsection{On tourist Perception}

Psychology indicates that the process of cognition and perception can be used to explain various behaviors. As the subject of tourism, tourist is the decision maker, which might cause a series of behavior. During this process, tourist's subjective judgment relies on many factors. Among them, the most important on is tourist tuition towards the objects and whether it meets visitors' needs and known by them. Therefore, the study on tourist's perception could help to understand and predict tourism decisive behavior so as to offer important founda- 
tion for planning and development of destination and product.

It has been proved that tourist perception will work on the formation of their preference, behavior, motive and attitude. Chen, Qiao, \& Liu (2009) study on the relationship between tourist risk perception and tourist behavior preference after the empirical investigation on tourists in Beijing. Li, Chen, \& Zhang (2007) concluded that tourist perception and preference played a significant role for cultural heritage tourism destination with the study of Pingyao Town. Luo, $\mathrm{Wu}, \&$ Deng (2007) investigated perception difference of entertainment usage influence from tourist with difference entertainment motives.

Tourist perception does not only affect one's decisive behavior, it is of reference role for evaluating tourism destination. Shi et al. (2008) study tourism destination competitiveness in the perspective of tourist perception. Yang and $\mathrm{Li}$ (2007), and Liu et al. (2005) assessed the development of tourism destination in the city of Xian, Kanasi, Guizhou in the angle of tourist perception.

Most scholars hold the idea that it bears the supportive role of perceptive value for satisfaction and purchase willingness. For example, Zhang (2009) and Tong and Yang (2009) took resort visitor as the cases, Shi and Liu (2009) chose visitors in Jiuzhaigou and Lushan mountain as the objects, Huang \& Huang (2008) and Chen (2006) took visitors in Kaifeng city, south-west tribe region as the case study to prove it is a truth. Tian \& Bao (2005) did the research on tourist satisfaction in the perspective of authenticity through empirical study on Dai Dance in Xishuangbanna. Feng and Sha (2007) set up an evaluation model of "authenticity-satisfaction" in the perspective of tourist perception with the case study of Wuyuan in Jiangxi province. This model composes of five factors such as authenticity perception of historic building, authenticity perception of lifestyle, authenticity of historic town, tourist satisfaction, tourist loyalty and $16 \mathrm{ob}-$ serving factors which might affect them.

\subsection{On Affecting Factor of Visitors' Authenticity Perception}

As for the factor affecting tourist's authenticity perception, Cohen proposed that there was different criterion on authenticity from various type of tourists (Cohen, 1988). Alison, Richard verified the authenticity by interviewing British tourists who visited historic and cultural heritage. They chose 1200 tourists who visited three different theme parks in Britain and emphasized the diversity of acquiring authenticity perception. Goulding (2000) found three approaches of tourist's perception. "Existing type" tourists were full of awareness of enjoyment and avoidance, they would percept the authenticity by handicrafts. "Aesthetical" tourists would percept history through art. While "social" tourists attach attention on the significance of learning and social experience, who would arouse the interests on display and purchasing in museum stores. In China, $\mathrm{Hu}$ (2010) made research on tourists' perception on industrial heritage authenticity in Shanghai and concluded that there were five factors affecting tourists' authentic- 
ity evaluation, they were, authenticity perception of industrial heritage building, authenticity perception of industrial culture, authenticity of industrial heritage, tourist satisfaction and authenticity perception of tourism products.

In conclusion, all the foreign researches show that the authenticity is the core value of cultural heritage. And authenticity plays a vital and special role for the development and protection of cultural heritage. At present, scholars study the intangible cultural heritage authenticity mainly from the perspective of concept discussion. Though Chinese research begins to use empirical analysis to study the perception of cultural heritage authenticity, there is not much research about the intangible culture heritage authenticity perception, Therefore, this paper tries to propose the index to affect authenticity content of intangible cultural heritage. Through studying tourists' perception difference, the authors adopt the principal component analysis to figure out the core factor, and regression equation will be used to verify the relationship between tourist's perception and satisfaction towards intangible cultural heritage authenticity.

\section{Framework and Method}

\subsection{Perception}

Perception is a series of simple reflections (such as see, taste, listen, smell and touch) of human sensory organ from object issues. It is a reflection and experience from the individual about an attribute of something. Comparing with perception, consciousness is the mental reflection of an object which directly working on sensory organs. Visitors' consciousness will be influenced by three major parts, first is stimulating factors, incentive's attributes, that is, size, color, sound, structure, shape and environment etc. The second is individual factor, for example, tourism objects, events or consciousness of some tourism items. The third concerns tourists' demographic characteristics, that is, their gender, income, age, occupation etc.

\subsection{Expectation}

It is people's memory combination from our own experience and acquired external information, which include an emotional need and attitude toward external object. And tourism expectation is affected by tourists' previous knowledge, experience and destination marketing status.

\section{Method}

\section{1) ANOVA Analysis}

Variance is an investigation on mean value difference between groups to evaluate whether it exists real global difference and significance. That is, under the settings of homogeneity of variance, it will test whether the average of several individual normal population mean $N\left(\mu_{i}, \sigma^{2}\right)(i=1,2, \cdots, r)$ is the same. Its maths formula is: 


$$
x_{i j}=\mu+\alpha_{i}+\varepsilon_{i j},\left(i=1,2, \cdots, r ; j=1,2, \cdots, n_{i}\right)
$$

$\mu, \alpha_{i} \quad(i=1,2, \cdots, r)$ is unknown parameter.

This study mainly analyses the significant difference of various variables from visitors with difference characteristics.

2) Independent sample T Test

$\mathrm{T}$ Test for two independent sample is to use two gross independent samples to deduce whether these tow gross averages contain significant different. It will be adopted to study perception difference of visitors with different gender.

3) Principal Component Analysis

Principal component Analysis in Factor analysis is borrowing the idea of dimension reduction to integrate many indexes into a few relevant comprehensive index, which is mainly used in the field of psychology, medication and economy. Its mathematic principle is to make original $\mathrm{P}$ indexes as linear combination to be the new comprehensive index. And we name the first one as F1, the principle to choose this linear combination is to put $\operatorname{Var}(\mathrm{F} 1)$, that is, F1 is the first principal component, then we choose the second principal component F2 with the same selection rules with the condition of $\operatorname{Cov}(\mathrm{F} 1, \mathrm{~F} 2)=0$ and so on to construct the rest principal components. This paper focuses on the extraction of the factors to influence visitors' perception of authenticity.

\subsection{Empirical study of Boluodan in Nanhai Temple}

\subsubsection{Brief Introduction}

Boluodan in Nanhai Temple is hold in every Lunar February $11^{\text {th }}-13^{\text {th }}$, and the day $13^{\text {th }}$ is the birthday of Boluo, this is also regarded as the Birthday of Nanhai Sea God. This event is originated from Tang Dynasty, is seen as the most special traditional and folk event in Guangzhou, even along Zhujiang River Delta region, it is also the biggest folk Temple event, and the only sacred ocean event in China.

Nanhai Temple is known as "Boluo Temple" which locates in Huangpu District of Guangzhou City. It is built by worshipping Zhu Rong, the Sea God of Nanhai Ocean. It is also the oldest port in China with the history of 1410 years. What's more, it is the biggest, oldest and the most completed maintained Sea God Temple all of China, is one of the birth places of Maritime Silk Road with large number of ancient inscriptions in the temple. And it was ranked as the Key protection historic relics of Guangdong Province in June, 1962. As it was rebuilt in the style of Ming and Qing Dynasty in 1985, it is named as one of the most attractive scenery spots in Guangzhou.

In 2007, this event was approved by Guangdong government as the second batch of provincial intangible cultural heritage. And it won the prize of public participation, and Top Ten Folk Event in China. In the May of 2015, it was selected in the third batch of national intangible culture heritage List and Expanded list. 


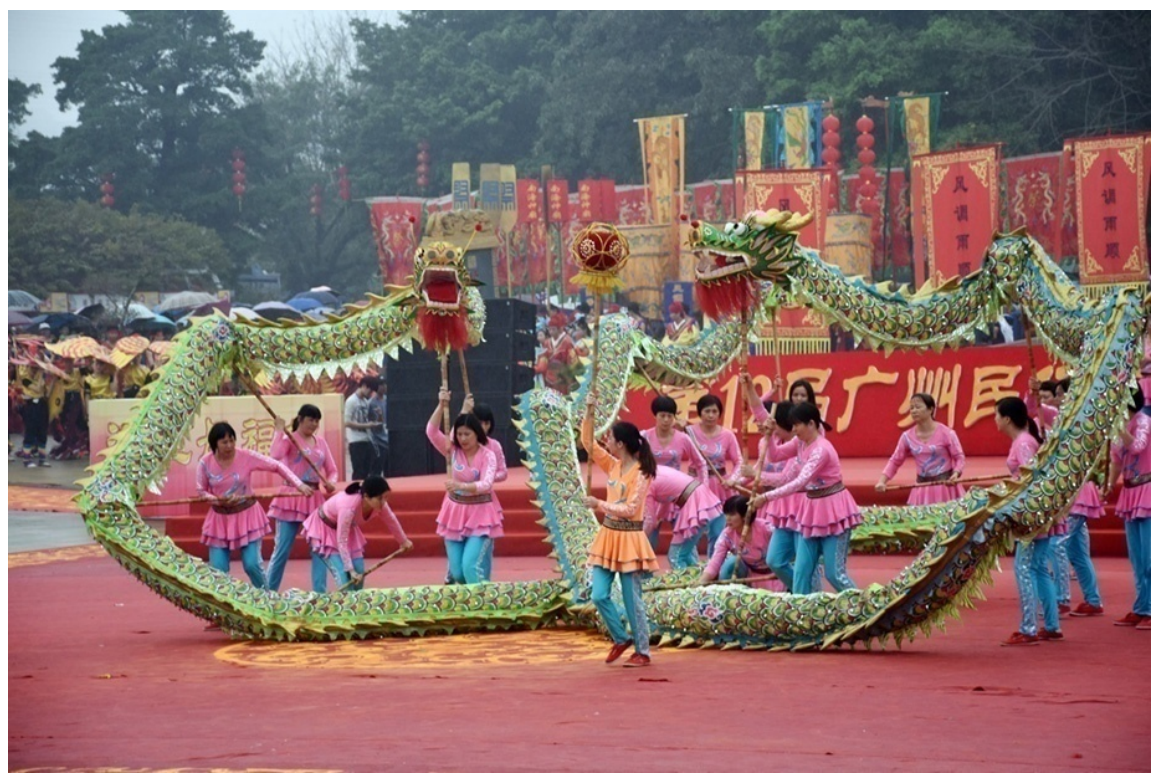

The event of Temple fair of Boluodan contains diversified activities such as handicrafts, food, convention, worship etc. to display local art of Guangzhou. Since 2005, it has grown to be one of renowned folk cultural brand for public tourism and leisure along Zhujiang River Delta district. There are some traditional foods or conventions. Boluo Chick, it is a handicraft made by paper and feather to pray for lucks and fortune. A traditional food named Boluo dumpling has the history of 800 years. As the most traditional activity in Nanhai Sea God Temple, sea worship activity is the residents' routine event to pray for fortune and luck. And there are other entertainments such as costume parade, dragon-lion dance and flower fair etc.

There are three reasons for us to choose Boloudan event as the case. Firstly, it is an event with more than one thousand years full of folk cultural connotation. Because there are more than 100 thousand people enjoying this event for pray, sightseeing, entertainment, food or shopping etc. It has become a part life for the residents with profound influence. Secondly, this event has been selected into the list of provincial intangible cultural heritage, and recommended to the third batch of national intangible cultural heritage list. So far, this event has been organized for 7 times, which proves that it has grown to be very successful with full value of reference. Thirdly, we have noticed that the government support for this event is only in the maintenance of its surrounding and restoration of cultural relics. However, the essence of intangible cultural heritage protection is far more than the protection of hardware. Ignorance of the enhancement of spiritual level will lose the target of the original purpose of intangible cultural heritage protection. Therefore, the study of visitor's perception on this event will effectively help us know how people see it and think of it, and their understanding and experience will surely offer us a comprehensive vision on how to build its software, that is, its cultural essence. 
In a word, the development of Boluodan Temple fair mirrors a problem in intangible cultural heritage tourism development, people pay too much concern about physical carrier, rather than culture perspective. Our study is expected to promote its development. Meanwhile, it could offer suggestions and opinions for other intangible cultural heritage protection.

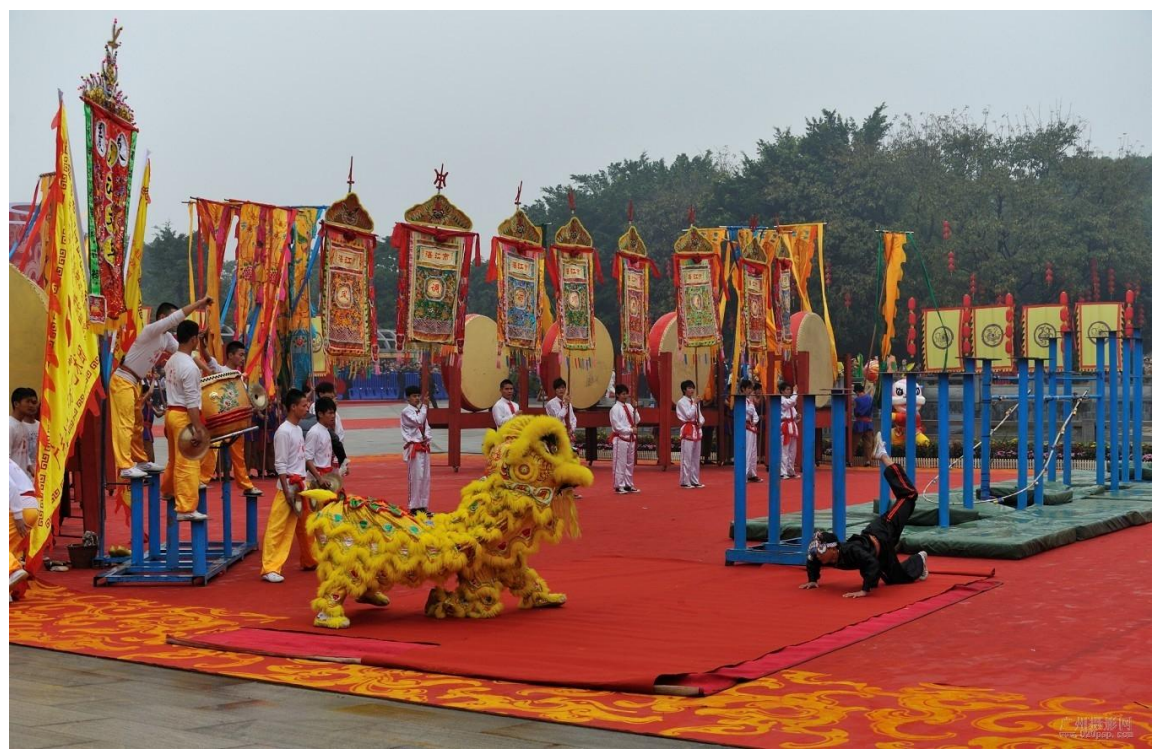

\subsubsection{Object Selection}

As there is no identified criterion for authenticity, this study mainly adopted Prof. Wang Ning's opinion on it. That is, objective authenticity involves the perception about architecture style, impression, internal design of the building and street. Constructive authenticity is the visitors' reflection of value, expectation, preference, image and opinion towards travel object. Existing authenticity concerns tourist, including their feeling, emotion, understanding and spiritual experience to culture. After the literature study and field trip, combining the idea from Tian Meirong and Kuang Wen, the authors work out following influential factors for this event (Table 1).

Table 1. Element analysis of Boluodan.

\begin{tabular}{cccc}
\hline Number & Item & Number & Item \\
\hline 1 & the attraction from historic relics & 7 & Detailed Pamphlets \\
2 & Beautiful surrounding scenery & 8 & Atmosphere \\
3 & Traditional craftsmanship & 9 & Commercialization \\
4 & $\begin{array}{c}\text { Boluo Chicken with new material } \\
\text { which losing original Characteristics }\end{array}$ & 10 & The knowledge \\
about history
\end{tabular}




\section{1) Questionnaire and analysis}

\section{2) Research design and field investigation}

The study design, through the questionnaire survey of tourists' authenticity perception of Boluodan Temple Fair, assesses the development effect of Boluodan Temple Fair and offer opinions and suggestions for the development and protection of Boluodan Temple Fair. The first part of the questionnaire involves the study on the tourists' experience, expectations and motivation of Boluodan. The second part uses Likert 5 subscales to measure the visitors' perception degree of authenticity; 1 means completely disagree, 2 means agree a little; 3 means whatever; 4 means somewhat agree and 5 means completely agree. The third part collects demographic data such as the information about tourists' gender, age, education, occupation, income and population characteristics. The authors conduct the research by one-on-one interview in March of 2015. There are a total of 600 questionnaires, and 565 valid questionnaires.

\subsubsection{Data Analysis}

Major part of visitors in Boluodan is the residents in Guangzhou city or the ones who live and work along Zhujing River Delta. The data indicates that in our field survey, there are 288 male visitors, and 277 female, which is in an appropriate gender proportion. The visitor younger than 20 is in $9.4 \%$, the ones from $21-34$ are in $57.5 \%$, the ones more than 35 is in $18.8 \%$, the people above 65 is $3.5 \%$. So we could see the visitors are mainly young and middle-aged people. It is opposite with our hypothesis that the main visitors are aged people. The first reason is health condition of senior people, the second is senior people often spend much less time there, just for pray. In terms of career, the people working in government and institution are the major part of visitors. For income, it is indicated that visitors belong to the ones with middle or low income, which occupies 92.6\%. And the education background of visitors ranges from high school, technical school to bachelor degree (Table 2).

Table 2. Demographic statistics of visitor.

\begin{tabular}{|c|c|c|c|c|c|c|c|}
\hline & & Count & Column N \% & & & Count & Column N \% \\
\hline \multirow{3}{*}{ Gender } & male & 288 & 51.0 & \multirow{4}{*}{ Income } & 2000 or less than & 165 & 29.2 \\
\hline & Female & 277 & 49.0 & & $2000-3000$ & 222 & 39.3 \\
\hline & 20 or younger & 53 & 9.4 & & $3000-5000$ & 138 & 24.1 \\
\hline \multirow{4}{*}{ Age } & $21-34$ & 325 & 57.5 & & 5000 or more than & 40 & 7.1 \\
\hline & $35-50$ & 106 & 18.8 & \multirow{7}{*}{ Occupation } & students & 97 & 17.2 \\
\hline & $51-64$ & 61 & 10.8 & & $\begin{array}{l}\text { Working for government } \\
\text { or institution }\end{array}$ & 85 & 15.0 \\
\hline & 65 or more & 20 & 3.5 & & Company's employee & 230 & 40.7 \\
\hline \multirow{4}{*}{ Education } & Under middle school & 88 & 15.6 & & farmer & 12 & 2.1 \\
\hline & High school technical school & 194 & 34.3 & & self-employed & 39 & 6.9 \\
\hline & college, university & 256 & 45.3 & & the retired & 71 & 12.6 \\
\hline & Master degree or more & 27 & 4.8 & & other & 31 & 5.5 \\
\hline
\end{tabular}


1) Visitor's behavior variable statistics

a) Purpose of visiting

The data indicates that worship is the main reason for people being there (there are 332 interviewees). It is a traditional occasion for people in the region. Then other purposes will be taken into visitors' account, for example, sightseeing, experiencing local culture, for leisure, for food. Those are many younger visitors' motive to be here. What's more, buying handicrafts such as Boluo Chicken, Boluo windmill, gathering with familiars and friends are goals for some part of visitors.

b) Way of visiting

The statistics show that more than $80 \%$ visitors choose to be there with familiar and friends. About $8 \%$ people come by themselves, only $6 \%$ people are coming for company or organization's incentive trip. $61.4 \%$ people travel here for the first time, $22 \%$ visit here for the second or third time. $16.6 \%$ people participate in this event for more than 3 times. Another survey from government proves that there has been increasing number of visitors in Boluodan since 2005, ranging from 300 thousand to 720 thousand.

c) The channel of getting information

The major way of people's information about this event is from the introduction of friend and TV programme. And some part of them is to know the information from book and on-line information. Few people get to know it from tourism pamphlet. The statistics also tell us a fact that only $9.2 \%$ people know the Boluodan well, $61.4 \%$ people have general idea, and $29.4 \%$ people know little about it.

2) Impact analysis of demographic variable on Boluodan authenticity perception

The authors will analyze the variables such as the historical site, surrounding scenery, promotional materials, Boluoji technology, new material, performance, atmosphere, commercialization, understanding of history and legends, religion and spirit, ICH title tec. according to different Boluodan tourists' gender, age, income, education level and occupation (Table 3).

The data indicates that both male and female hold higher authenticity perception in the aspects of historical relics of Nanhai Temple, traditional folk performance, and overall assessment of Boluodan. However, there are some perception differences among them because of different gender. For example, men hold relatively higher perception than women in the aspects of historic relics, new trend of folk culture and overall impression of Boluodan. The main reason is male visitors show more interests in history than women with more detailed observation, so they are able to attain more background information. In surrounding environment (Mean for male $=3.47$, Mean for female $=3.59$ ), participation (Mean for male $=3.02$, Mean for female $=3.12$ ), perception on religious and spiritual experience $($ Mean for male $=3.25$, Mean for female $=3.30$ ), we could see, female is in higher degree in curiosity and willingness to participate in some events. 
Table 3. Authenticity perception on Boluodan from visitors with different gender.

\begin{tabular}{ccccc}
\hline Variable & Male Mean & Female Mean & $\mathrm{T}$ & $\mathrm{P}$ \\
\hline the attraction from historic relics & 4.02 & 3.88 & 2.424 & .789 \\
Beautiful surrounding scenery & 3.47 & 3.59 & 2.428 & .001 \\
Detailed brochure or information & 3.62 & 3.60 & -1.581 & .941 \\
Traditional craftsmanship & 3.59 & 3.56 & -1.585 & .787 \\
Boluo Chicken with new material & 3.40 & 3.35 & .278 & .292 \\
which losing original Characteristics & & & & .347 \\
Boluo Dumpling & 3.68 & 3.65 & .278 & .347 \\
Particular performance & 3.83 & 3.79 & .383 & .927 \\
Atmosphere & 3.91 & 3.87 & .780 & .982 \\
Commercialization & 3.76 & 3.78 & .326 & .405 \\
The understanding of history and legend & 3.45 & 3.48 & .326 & .572 \\
Religion and Spirit & 3.25 & 3.30 & .631 & .166 \\
Title of intangible heritage & 3.77 & 3.72 & .631 & .801 \\
\hline
\end{tabular}

a) Perception on Boluodan from visitors with different gender

In terms of authenticity perception of historical relics, the visitor with the age of 21 - 34 and the one in 35 - 50 hold significant difference. On one hand, 21 - 34 group know less information about Nanhan Temple than 35 - 50 group. On the other hand, they tend to go there for entertainment rather than getting information. As for authenticity perception of surrounding scenery, there are significantly different among people in different ages. 21 - 34 group has great demand in the surrounding scenery. They are quite sensitive on the emission from ship factory of Boluo Temple. While visitor younger than 20, most of them are students, concern less about environment, and the people above 65, are revisitors of Boluodan, they live near the place, the maintenance and restoration of the physical environment in recent years increase their satisfaction.

In terms of authenticity perception on production technology, tourists over 65 have a pretty good idea of the traditional production process of Boluo Chicken; while 35 - 50, 51 - 64 group see it as inheritance, the representative of the traditional culture; 21 - 34 tourists know little about this craftsmanship, they are even not sure whether the process is traditional. In the aspect of the production process of new technology of Boluo chicken, tourists in age of 21 - 34 think the appropriate change of Boluo chick material proves a sign of advancement with the times; while visitors under the age of 20 , the students, they love to keep the totally traditional production craft process. In terms of authenticity perception of Boluo chicken, the tourist under the age of 20, don't think eating Boluo dumpling in Boluodan is a reflection of tradition; while the older tourists agree that this food contains distinguished feature, as the expression of the continuation of 
traditional customs. As for perception of the traditional performance, visitors over 65 are so happy to see the rejuvenation of traditional culture. While poor information about this event from visitors in other age group negatively affect their perception on it. We could also see the tourists under 20 get higher satisfaction on religious and spiritual experience (Mean $=3.40)$.

b) Perception on Boluodan from visitors with different education background We study the perception of authenticity in Boluodan from people with different educational background by single factor variance and Pearson correlation coefficient, the data from single factor variance indicates there is no significant difference in the traditional production process, performance characteristics, atmosphere, commercialization and the understanding of the history and legend. Pearson correlation indicates the more education people receive, the more interests and understanding they can do $\left(\beta=.101^{*}\right)$. What's more, people have more education will demand more for tourism facility, environment and product, but lower satisfaction in religious and spiritual experience $\left(\beta=-.141^{* *}\right)$. From the data of single factor variance, we could see people with different education background have significant difference on religious and spiritual experience. On the issue whether Boluodan could be entitled as provincial intangible cultural heritage, it shows negative correlation with education background. ( $\beta=$ $-.095^{\star}$ ) As we all know, people's perception is closely related with education background, the more we learned, the deeper we might percept. That is why the statistics show that people with high school or technical school education have significant difference with those who graduate from university.

c) Perception on Boluodan from visitors with different education career

When significance $\leq .05$, it means there exist significant difference in data. We could see from Tables 4-7, visitors from different careers have different authenticity perception only in perspective of traditional handicraft and atmosphere.

The data indicates that the self-employed (mean $=3.67$ ), the people working in the government or institution (mean $=4.08$ ) company employee (mean $=$ $3.98)$, the retired (mean $=3.99$ ) have significant difference on the perception about cultural heritage authenticity, and beauty of surrounding scenery. We could see the self-employed have to sustain more pressure with higher payment, they tend to be critical towards the event, while the retired people are more familiar with traditional culture and they have more awareness on the intangible culture heritage, that is why they have more positive assessment than other groups. What's more, the retired people have highest recognition on commercialization (mean $=3.89$ ). Because they think commercialization could help the rejuvenation of traditional culture. It goes well with the idea of Cohen (1988) that when tradition was lost in modern society, commercial purpose could help to maintain the traditional culture and vitality of convention. And the retired people have the most motive to recommend friends revisit the place (mean = 4.07). However, farmer has the lower recognition on commercialization for they receive the least economic benefit from it. 
Table 4. Single factor analysis on authenticity perception difference among visitors with different ages.

\begin{tabular}{|c|c|c|c|c|c|c|c|}
\hline \multirow{2}{*}{ Dependent variable } & \multirow{2}{*}{ (I) Age } & \multirow{2}{*}{ (J) Age } & \multirow{2}{*}{$\begin{array}{c}\text { Average } \\
\text { difference (I - J) }\end{array}$} & \multirow{2}{*}{ Standard Error } & \multirow{2}{*}{ significance } & \multicolumn{2}{|c|}{$\begin{array}{l}\text { 95\% confidence } \\
\text { interval }\end{array}$} \\
\hline & & & & & & $\begin{array}{c}\text { Next } \\
\text { session }\end{array}$ & $\begin{array}{c}\text { Previous } \\
\text { session }\end{array}$ \\
\hline \multirow[t]{2}{*}{ Historical relics } & $21-34$ & $35-50$ & $-.171^{\star}$ & .077 & .027 & -.32 & -.02 \\
\hline & 20 or younger & $21-34$ & $.390^{*}$ & .133 & .003 & .13 & .65 \\
\hline \multirow[t]{3}{*}{ Surrounding scenery } & $21-34$ & $\begin{array}{l}65 \text { or older } \\
\text { above } 65\end{array}$ & $-.410^{\star}$ & .206 & .047 & -.82 & 0 \\
\hline & 20 or younger & above 65 & $-.584^{*}$ & .218 & .008 & -1.01 & -.16 \\
\hline & $21-34$ & $35-50$ & $-.255^{\star}$ & .093 & .006 & -.44 & -.07 \\
\hline \multirow[t]{3}{*}{ craftsmanship } & $21-34$ & $51-64$ & $-.351^{\star}$ & .116 & .003 & -.58 & -.12 \\
\hline & $21-34$ & Above 65 & $-.698^{*}$ & .191 & 0 & -1.07 & -.32 \\
\hline & $35-50$ & Above 65 & $-.442^{*}$ & .202 & .029 & -.84 & -.05 \\
\hline \multirow[t]{2}{*}{$\begin{array}{l}\text { Boluo chicken with } \\
\text { new material }\end{array}$} & 20 or younger & $21-34$ & $-.261^{*}$ & .126 & .04 & -.51 & -.01 \\
\hline & 20 or younger & $21-34$ & $-.307^{\star}$ & .127 & .016 & -.56 & -.06 \\
\hline \multirow{3}{*}{ Boluo Dumpling } & & $35-50$ & $-.434^{*}$ & .144 & .003 & -.72 & -.15 \\
\hline & & $51-64$ & $-.431^{\star}$ & .16 & .007 & -.75 & -.12 \\
\hline & & Above 65 & $-.610^{*}$ & .224 & .007 & -1.05 & -.17 \\
\hline \multirow{2}{*}{ Performance } & $21-34$ & Above 65 & $-.462^{*}$ & .17 & .007 & -.79 & -.13 \\
\hline & $35-50$ & Above 65 & $-.360^{*}$ & .18 & .045 & -.71 & -.01 \\
\hline \multirow[t]{2}{*}{$\begin{array}{l}\text { The understanding } \\
\text { of history and legend }\end{array}$} & $21-34$ & Above 65 & $-.400^{*}$ & .196 & .042 & -.79 & -.01 \\
\hline & 20 or younger & Above 65 & $-.554^{*}$ & .248 & .026 & -1.04 & -.07 \\
\hline \multirow{3}{*}{ Religion and spirit } & $21-34$ & Above 65 & $-.775^{*}$ & .217 & 0 & -1.2 & -.35 \\
\hline & $35-50$ & Above 65 & $-.601^{*}$ & .23 & .009 & -1.05 & -.15 \\
\hline & $51-64$ & Above 65 & $-.606^{*}$ & .243 & .013 & -1.08 & -.13 \\
\hline \multirow{4}{*}{$\begin{array}{l}\text { Title of intangible } \\
\text { cultural heritage }\end{array}$} & 20 or younger & $21-34$ & $.310^{*}$ & .11 & .005 & .09 & .53 \\
\hline & $21-34$ & $51-64$ & $-.217^{*}$ & .104 & .037 & -.42 & -.01 \\
\hline & $21-34$ & Above 65 & $-.498^{*}$ & .171 & .004 & -.83 & -.16 \\
\hline & $35-50$ & Above 65 & $-.376^{\star}$ & .181 & .038 & -.73 & -.02 \\
\hline
\end{tabular}

The list only including the items with significant difference for too many charts.

d) Perception on Boluodan from visitors with different income

Pearson correlation coefficient indicate, in the precondition of $P=.01$, the people with different income have significant positive correlation in authenticity perception towards Boluo dumpling. $\left(\beta=.116^{* *}\right)$, that is the more income people receive, the higher perception they will have. The field trip found that the price of Boluo dumpling is three times more than that of the regular dumpling. 
Table 5. ANOVA Analysis on authenticity perception difference among visitors with different education background.

\begin{tabular}{|c|c|c|c|c|c|c|c|}
\hline \multirow{2}{*}{ Independent variable } & \multirow{2}{*}{$\begin{array}{c}\text { (I) } \\
\text { Education }\end{array}$} & \multirow{2}{*}{$\begin{array}{c}(\mathrm{J}) \\
\text { Education }\end{array}$} & \multirow{2}{*}{$\begin{array}{l}\text { (I - J) Average } \\
\text { difference }\end{array}$} & \multirow{2}{*}{$\begin{array}{l}\text { Standard } \\
\text { Error }\end{array}$} & \multirow{2}{*}{ Significance } & \multicolumn{2}{|c|}{$\begin{array}{l}95 \% \text { confidence } \\
\text { interval }\end{array}$} \\
\hline & & & & & & $\begin{array}{l}\text { Next } \\
\text { session }\end{array}$ & $\begin{array}{c}\text { Previous } \\
\text { session }\end{array}$ \\
\hline $\begin{array}{l}\text { The attraction } \\
\text { of historical relic }\end{array}$ & $\begin{array}{l}\text { Middle school } \\
\text { and below }\end{array}$ & $\begin{array}{l}\text { High school, technical } \\
\text { school, college, } \\
\text { university and graduates }\end{array}$ & $-.228^{*}$ & .088 & .010 & -.40 & -.06 \\
\hline $\begin{array}{l}\text { Beautiful } \\
\text { surrounding }\end{array}$ & High school or & & $-.207^{\star}$ & .085 & .015 & -.37 & -.04 \\
\hline scenery & technical school & $\begin{array}{l}\text { Technical school, } \\
\text { and university }\end{array}$ & $-.387^{\star}$ & .151 & .011 & -.68 & -.09 \\
\hline $\begin{array}{l}\text { Detailed brochure } \\
\text { and information }\end{array}$ & $\begin{array}{l}\text { Middle school } \\
\text { and below }\end{array}$ & Master & $.212^{*}$ & .086 & .014 & .04 & .38 \\
\hline $\begin{array}{l}\text { Boluo Chicken with new } \\
\text { material which losing }\end{array}$ & $\begin{array}{l}\text { Technical school } \\
\text { and university }\end{array}$ & Master & $-.415^{*}$ & .176 & .019 & -.76 & -.07 \\
\hline original Characteristics & & & $-.371^{\star}$ & .161 & .022 & -.69 & -.05 \\
\hline \multirow[t]{2}{*}{ Boluo Dumpling } & $\begin{array}{l}\text { High school, } \\
\text { technical school }\end{array}$ & College and university & $-.183^{\star}$ & .081 & .025 & -.34 & -.02 \\
\hline & $\begin{array}{l}\text { Middle school } \\
\text { and below }\end{array}$ & Master & $-.429^{*}$ & .189 & .024 & -.80 & -.06 \\
\hline \multirow{2}{*}{ Religion and Spirit } & $\begin{array}{l}\text { Middle school } \\
\text { and below }\end{array}$ & College and university & $.292^{*}$ & .116 & .012 & .06 & .52 \\
\hline & $\begin{array}{l}\text { High school and } \\
\text { technical school }\end{array}$ & College and university & $.326^{*}$ & .090 & .000 & .15 & .50 \\
\hline $\begin{array}{l}\text { Title of intangible } \\
\text { culture heritage }\end{array}$ & $\begin{array}{l}\text { High school and } \\
\text { technical school }\end{array}$ & College and university & $.175^{*}$ & .071 & .015 & .03 & .32 \\
\hline
\end{tabular}

Table 6. Correlation analysis on authenticity perception of people with different education background.

\begin{tabular}{lc}
\hline \multicolumn{1}{c}{ Item } & Pearson Correlation coefficient (education* items) \\
\hline The attraction of historical relic & $.101^{*}$ \\
Beautiful surrounding scenery & -.073 \\
Detailed brochure and information & .033 \\
Traditional craftsmanship & -.035 \\
Boluo Chicken with new material which losing original characteristics & .079 \\
Boluo dumpling & .060 \\
Particular performance & -.015 \\
Atmosphere & -.020 \\
Commercialization & -.022 \\
The understanding of history and legend & .002 \\
Religion and spirit & $-.141^{\star *}$ \\
Title of intangible culture heritage & $-.095^{\star}$ \\
Willingness to revisit next year & $-.173^{* *}$ \\
\hline
\end{tabular}


Table 7. ANOVA Analysis on authenticity perception difference among visitors with different career.

\begin{tabular}{|c|c|c|c|c|c|}
\hline Variable & $\begin{array}{l}\text { Sum of } \\
\text { Squares }\end{array}$ & $\mathrm{df}$ & $\begin{array}{l}\text { Mean } \\
\text { Square }\end{array}$ & $\mathrm{F}$ & Sig. \\
\hline The attraction of historical relic & 5.668 & 6 & .945 & 2.012 & .062 \\
\hline Beautiful surrounding scenery & 9.510 & 6 & 1.585 & 1.969 & .068 \\
\hline Detailed brochure and information & 3.146 & 6 & .524 & .814 & .559 \\
\hline Traditional craftsmanship & 14.354 & 6 & 2.392 & 3.442 & .002 \\
\hline $\begin{array}{l}\text { Boluo Chicken with new material } \\
\text { which losing original Characteristics }\end{array}$ & 7.688 & 6 & 1.281 & 1.766 & .104 \\
\hline Boluo dumpling & 6.080 & 6 & 1.013 & 1.374 & .223 \\
\hline Particular performance & 5.448 & 6 & .908 & 1.664 & .128 \\
\hline Atmosphere & 8.283 & 6 & 1.381 & 2.881 & .009 \\
\hline Commercialization & 4.095 & 6 & .683 & 1.174 & .319 \\
\hline $\begin{array}{l}\text { The understanding } \\
\text { of history and legend }\end{array}$ & 7.432 & 6 & 1.239 & 1.714 & .115 \\
\hline Religion and Spirit & 6.674 & 6 & 1.112 & 1.227 & .291 \\
\hline The title of Intangible Culture Heritage & 3.714 & 6 & .619 & 1.095 & .364 \\
\hline Willingness to revisit next year & 13.243 & 6 & 2.207 & 3.407 & .003 \\
\hline
\end{tabular}

The people with high income have more capacity to purchase, so tasting dumpling is one of their activities in this event, but the people will less income will not do it. The data from single factor variance shows that the more income the people have, the more difference their perception will be.

The data show that with the increase of income, authenticity perception towards pamphlets and handicraft of traditional Boluo chicken will grow. Because well-paid people, to some extent, refer to those who receive higher education, they, therefore, pay more attention to the brochure and pamphlets about the event. In single factor variance analysis, there is significant difference in perception about pamphlets between people with income less than 2000 RMB and those with 3000 - $5000 \mathrm{RMB}$. What's more, the people with more income will show more interested in traditional handicraft in Boluo Chick.

\section{3) Expectation and Satisfaction Analysis}

We did research on visitors' expectation in the questionnaire (see Tables 4-11), $68.5 \%$ of people expect to experience traditional Boluodan custom. 55.6\% want to know folk culture, $15.9 \%$ hope to be close to the God to get luck or fortune, $15.2 \%$ of them want to entertain themselves, while $2.3 \%$ of people's goal is to know local people. It terms of the attitude to keep Boluodan's tradition, 20.5\% of people care a lot about it, 52.9\% of them care about it, only 3.9\% people don't think it is important. Hence, we could see, most people hold positive attitude toward this tradition. 
Table 8. ANOVA analysis of comparative study of different occupations.

\begin{tabular}{|c|c|c|c|c|c|c|c|}
\hline \multirow{2}{*}{ Dependent variable } & \multirow{2}{*}{$\begin{array}{c}\text { (I) } \\
\text { occupation }\end{array}$} & \multirow{2}{*}{$\begin{array}{c}(\mathrm{J}) \\
\text { Occupation }\end{array}$} & \multicolumn{2}{|c|}{ (I - J)Average Standard } & \multirow{2}{*}{ significance } & \multicolumn{2}{|c|}{$\begin{array}{c}995 \% \text { confidence } \\
\text { interval }\end{array}$} \\
\hline & & & Difference & Error & & $\begin{array}{c}\text { Next } \\
\text { session }\end{array}$ & $\begin{array}{l}\text { Previous } \\
\text { session }\end{array}$ \\
\hline $\begin{array}{l}\text { The attraction } \\
\text { of historical relic }\end{array}$ & Self-employee & $\begin{array}{l}\text { The staff in } \\
\text { government and institution }\end{array}$ & $-.416^{\star}$ & .133 & .002 & -.68 & -.16 \\
\hline \multirow[t]{2}{*}{$\begin{array}{l}\text { Beautiful surrounding } \\
\text { scenery }\end{array}$} & farmer & Employee in company & $-.312^{*}$ & .119 & .009 & -.54 & -.08 \\
\hline & Self-employee & retired & $-.319^{*}$ & .137 & .020 & -.59 & -.05 \\
\hline \multirow[t]{5}{*}{ Traditional craftsmanship } & retired & students & $.567^{\star}$ & .275 & .039 & .03 & 1.11 \\
\hline & & farmer & & .174 & .026 & -.73 & -.05 \\
\hline & & retired & $-.718^{*}$ & .296 & .016 & -1.30 & -.14 \\
\hline & & & $-.394^{*}$ & .179 & .028 & -.75 & -.04 \\
\hline & & students & $.435^{\star}$ & .130 & .001 & .18 & .69 \\
\hline \multirow{7}{*}{$\begin{array}{l}\text { Boluo Chicken with new } \\
\text { material which losing } \\
\text { original Characteristic }\end{array}$} & & Employee in company & $.243^{*}$ & .113 & .032 & .02 & .47 \\
\hline & & farmer & $.734^{*}$ & .260 & .005 & .22 & 1.24 \\
\hline & & Self-employed & $.355^{*}$ & .166 & .033 & .03 & .68 \\
\hline & & others & $.365^{*}$ & .179 & .042 & .01 & .72 \\
\hline & farmer & students & $-.620^{*}$ & .261 & .018 & -1.13 & -.11 \\
\hline & & Staff in government and institution & $-.637^{\star}$ & .263 & .016 & -1.15 & -.12 \\
\hline & & Employee in company & $-.541^{\star}$ & .252 & .033 & -1.04 & -.05 \\
\hline \multirow[t]{3}{*}{ Particular performance } & $\begin{array}{c}\text { staff in } \\
\text { government } \\
\text { and institution }\end{array}$ & Employee in company & $.190^{*}$ & .094 & .043 & .01 & .37 \\
\hline & retired & Employee in company & $.247^{*}$ & .100 & .014 & .05 & .44 \\
\hline & & & $.294^{*}$ & .147 & .047 & .00 & .58 \\
\hline Commercialization & retired & Staff in government and institution & $.252^{*}$ & .123 & .040 & .01 & .49 \\
\hline $\begin{array}{l}\text { The understanding } \\
\text { of history and legend }\end{array}$ & retired & Employee in company & $.283^{*}$ & .115 & .015 & .06 & .51 \\
\hline \multirow[t]{2}{*}{ Religion and Spirit } & retired & farmer & $.565^{*}$ & .265 & .034 & .04 & 1.09 \\
\hline & & student & $.307^{*}$ & .149 & .039 & .02 & .60 \\
\hline \multirow[t]{2}{*}{$\begin{array}{l}\text { The title of intangible } \\
\text { culture heritage }\end{array}$} & retired & student & $.253^{*}$ & .117 & .032 & .02 & .48 \\
\hline & & Employee in company & $.244^{*}$ & .102 & .017 & .04 & .44 \\
\hline \multirow{3}{*}{$\begin{array}{l}\text { Willingness to } \\
\text { revisit next year }\end{array}$} & retired & student & $.462^{*}$ & .126 & .000 & .22 & .71 \\
\hline & & Staff in government and institution & $.459^{*}$ & .129 & .000 & .20 & .71 \\
\hline & & Employee in company & $.418^{\star}$ & 109 & .000 & .20 & .63 \\
\hline
\end{tabular}


Table 9. ANOVA analysis on authenticity perception difference among visitors with different income (in RMB).

\begin{tabular}{|c|c|c|c|c|c|c|c|}
\hline \multirow[b]{2}{*}{ Dependent variable } & \multirow[b]{2}{*}{$\begin{array}{c}\text { (I) } \\
\text { income }\end{array}$} & \multirow[b]{2}{*}{$\begin{array}{c}(\mathrm{J}) \\
\text { income }\end{array}$} & \multirow[b]{2}{*}{$\begin{array}{c}(\mathrm{I}-\mathrm{J}) \\
\text { Average difference }\end{array}$} & \multirow[b]{2}{*}{$\begin{array}{l}\text { Standard } \\
\text { error }\end{array}$} & \multirow[b]{2}{*}{ significance } & \multicolumn{2}{|c|}{ confidence interval } \\
\hline & & & & & & $\begin{array}{c}\text { Nest } \\
\text { session }\end{array}$ & $\begin{array}{c}\text { Previous } \\
\text { session }\end{array}$ \\
\hline Detailed brochure and information & & $3000-5000$ & $-.187^{\star}$ & .092 & .044 & -.37 & -.01 \\
\hline \multirow[t]{2}{*}{ Traditional craftsmanship } & $2000 \mathrm{RMB}$ or less & $2000-3000$ & $-.298^{\star}$ & .086 & .001 & -.47 & -.13 \\
\hline & & $3000-5000$ & $-.247^{\star}$ & .097 & .011 & -.44 & -.06 \\
\hline \multirow[t]{3}{*}{ Boluo dumpling } & 2000 or less & $2000-3000$ & $-.192^{*}$ & .088 & .030 & -.37 & -.02 \\
\hline & & $3000-5000$ & $-.245^{\star}$ & .099 & .014 & -.44 & -.05 \\
\hline & & 5000 or more & $-.316^{*}$ & .151 & .037 & -.61 & -.02 \\
\hline \multirow[t]{2}{*}{ Religion and Spirit } & $2000-3000$ & 5000 or more & $.335^{*}$ & .163 & .041 & .01 & .66 \\
\hline & $3000-5000$ & 5000 or more & $.398^{*}$ & .171 & .020 & .06 & .73 \\
\hline The title of intangible cultural heritage & $2000-3000$ & 5000 or more & $.294^{*}$ & .129 & .023 & .04 & .55 \\
\hline
\end{tabular}

Table 10. Affecting factors analysis on authenticity perception from visitor with different income.

\begin{tabular}{|c|c|c|c|}
\hline Observing index & $\mathrm{F}$ & $\mathrm{P}$ & Pearson \\
\hline The attraction of historical relic & 1.113 & .343 & .073 \\
\hline Beautiful surrounding scenery & 1.239 & .295 & -.018 \\
\hline Detailed brochure and information & 1.675 & .171 & $.092^{*}$ \\
\hline Traditional craftsmanship & 4.405 & .004 & $.106^{*}$ \\
\hline Boluo Chicken with new material which losing original Characteristics & 1.624 & .183 & .023 \\
\hline Boluo dumpling & 2.911 & .034 & $.116^{* *}$ \\
\hline Particular performance & .905 & .439 & .064 \\
\hline Atmosphere & .436 & .727 & -.021 \\
\hline Commercialization & 1.007 & .389 & -.033 \\
\hline Understanding of history and legend & 1.506 & .212 & .063 \\
\hline Religion and Spirit & 1.833 & .140 & -.032 \\
\hline Title of intangible culture heritage & 1.999 & .113 & -.035 \\
\hline Willingness to revisit next year & 3.080 & .027 & -.037 \\
\hline
\end{tabular}

Table 11. Analysis of visitors' expectation and satisfaction about Boluodan.

\begin{tabular}{cccccc}
\hline Expected Coincidence degree & Percent & Evaluation & Percent & Satisfaction & Percent \\
\hline Totally the same & .9 & Commercialized behavior & 6.4 & Totally disagree & 1.2 \\
The same & 9.4 & Commercialization and some traditions are lost & 41.2 & disagree & 5.0 \\
Hard to say & 32.9 & Hard to say & 11.2 & Hard to say & 29.0 \\
Not same & 53.1 & Traditions are kept well & 25.1 & Agree & 50.4 \\
Totally not same & 3.7 & Traditions are carried on & 16.1 & Totally agree & 14.3 \\
Total & 100.0 & Total & 100.0 & Total & 100.0 \\
\hline
\end{tabular}




\section{4) Principal Component Analysis on affecting visitor's authenticity per- ception about Bolodan}

We extract three common factors after the first factor analysis, but as there only consists the factor of Boluo Chicken made by new material, the content validity will be influenced for one or two questions in one category, so we delete this question and category and start the second factor analysis. This study will make factor analysis on 11 factors about visitors' perception by SPSS17.0

$\mathrm{KMO}$ is sampling appropriateness of Kaiser-Meyer-Olkin. The bigger KMO is, the more common factors among variables, which is more suitable to be factor analysis. Tables 4-14 indicate KMO is 0.960 which is good for factor analysis. And Bartlett sphere testing Chi-square value (2736.124) which has reached the degree of significance, it refers to there are common factor among relative matrix, which is suitable for factor analysis.

Tables 4-14 indicate that, there chooses two factors among the 11, these two explain $73.69 \%$ variation. We figured out 2 core factors for influencing visitors' authenticity perception. The first factor includes, religion and spirit, the understanding of legend and history, title of intangible heritage, atmosphere, attraction from historical relics, surrounding scenery, commercialization; the second factors refers to handicraft tradition, Boluo dumpling, detailed brochure and particular performance etc.

Table 12. KMO and Bartlett's test.

\begin{tabular}{ccc}
\hline & Kaiser-Meyer-Olkin Sampling appropriateness & .960 \\
Bartlett & Approximate chi-square distribution & 2736.124 \\
Sphere testing & Degree of freedom & 55 \\
& significance & .000 \\
\hline
\end{tabular}

Table 13. Explanation of variance.

\begin{tabular}{|c|c|c|c|c|c|c|c|c|c|}
\hline \multirow{2}{*}{ component } & \multicolumn{3}{|c|}{ Initial Eigen values } & \multicolumn{3}{|c|}{ Sum of square load extraction } & \multicolumn{3}{|c|}{ Shaft square load } \\
\hline & sum & $\%$ variance $\%$ & accumulative $\%$ & sum & variance $\%$ & accumulative \% & sum & variance $\%$ & accumulative $\%$ \\
\hline 1 & 7.395 & 67.231 & 67.231 & 7.395 & 67.231 & 67.231 & 4.679 & 42.541 & 42.541 \\
\hline 2 & .711 & 6.463 & 73.694 & .711 & 6.463 & 73.694 & 3.427 & 31.153 & 73.694 \\
\hline 3 & .522 & 4.743 & 78.437 & & & & & & \\
\hline 4 & .456 & 4.148 & 82.585 & & & & & & \\
\hline 5 & .425 & 3.862 & 86.447 & & & & & & \\
\hline 6 & .384 & 3.492 & 89.939 & & & & & & \\
\hline 7 & .338 & 3.070 & 93.009 & & & & & & \\
\hline 8 & .223 & 2.031 & 95.040 & & & & & & \\
\hline 9 & .192 & 1.748 & 96.788 & & & & & & \\
\hline 10 & .185 & 1.681 & 98.469 & & & & & & \\
\hline 11 & .168 & 1.531 & 100.000 & & & & & & \\
\hline
\end{tabular}


Table 14. Factor loading table after rotation shaft.

\begin{tabular}{ccc}
\hline \multirow{2}{*}{ Factor } & Item & \multicolumn{2}{c}{ Component } \\
\cline { 3 - 3 } Religion and spirit & .870 & \\
\hline \multirow{2}{*}{ The understanding of history and legend } & .860 & \\
& Title of intangible culture heritage & .794 \\
atmosphere & .789 & \\
The attraction of historical relic & .707 & .819 \\
Beautiful surrounding scenery & .618 \\
commercialization & .600 & .815 \\
Traditional craftsmanship & & .591 \\
Boluo dumpling & & .584 \\
\hline
\end{tabular}

It only indicates the loading more than .5 .

\section{Discussion}

The study focuses on the analysis of perception difference in perspective of demographics in the way of SPSS, single factor analysis and Pearson correlation coefficient. And principal component analysis helps to extract core factors for the perception.

In terms of gender, male's authenticity perception on historical relics, new trend of folk culture, and overall impression about Boluodan is a bit higher than that of female. While female is more sensitive in perception on surrounding scenery, participation, religious and spiritual experience.

People in different age indicate significant difference in historical relics, surrounding scenery, handicraft, Boluo Chick with new material, Boluo dumpling, performance, the understanding of history and legend, religion and spirit, title of intangible culture. However, in the aspects of traditional handicraft, particular performance, atmosphere, commercialization, the understanding of history and legend, the people with different education background don't show significant difference.

People with different career have significant difference on the authenticity perception about traditional handicrafts and atmosphere. As for people with different income, there are significant difference in traditional handicrafts, Boluo dumpling and willingness of recommendation.

For the expectation and satisfaction analysis, we could see, the more acceptance people have for tradition, the higher degree of satisfaction for the Boluodan Temple fair. The study also works out two core factors of authenticity perception. 


\section{Implication}

This study offers the deeper perspective on the ICH authenticity perception, as there is even little research on the ICH authenticity protection through the perception. This paper tries to propose the index to affect authenticity content of intangible cultural heritage. Visitors' expectation, evaluation and attitude about intangible cultural heritage will affect their perception and satisfaction. What's more, their authenticity perception does not only involve the understanding on the physical carrier, but also contains the feeling about intangible ones. After data analysis on perception of visitors, the authors propose some suggestions to improve ICH development: firstly, the construction of spiritual culture should be concerned. The data indicate the factors such as religion and spirit, the understanding of history and legend, the title of ICH will contribute a lot about visitors' authenticity perception, and the intangible assets such as legend, story, should be full cultivated to enhance people's perception. Secondly, the role of mass media to publicize ICH should be stressed. It could effectively convey the information about traditional culture with many hi-tech approaches. Thirdly, in terms of scenery management and project design, hi-tech elements and interactive programme should be taken into account so as to make it well-known to the public. Fourthly, commercialized construction of traditional temple should be maintained in a balance. On the one hand, commercialization will help to publicize the traditional culture. On the other hand, over-development will be avoided to guarantee the authenticity of ICH. Fifthly, the characteristics of tourism products will be maintained to make the traditional culture go further.

In all, tourism development of ICH is more than to realize economic target. The more important is to introduce traditional culture to the public to make sure the inheritance and awareness of national culture in China.

The limitation of this study is that it only focuses on the analysis of visitors' perception after their travel, rather than the comparative study on pre- and post-visit perception. It could be the topic of future research. What's more, owning to the limited number of index, this research is not able to set up structural model between authenticity perception and satisfaction, which could also be a direction of further research.

\section{Acknowledgements}

This research is supported by the key project of National Social Science funding in the Number of 16AZD055.

\section{Conflicts of Interest}

The authors declare no conflicts of interest regarding the publication of this paper.

\section{References}

Apostolakis, A. (2003). The Convergence Process in Heritage Tourism. Annals of Tour- 
ism Research, 30, 795-812. https://doi.org/10.1016/S0160-7383(03)00057-4

Chen, N., Qiao, G. H., \& Liu, L. (2009). Study on Tourism Risk Perception and Preference Relevance of Outbound Visitors-Case Study of Beijing Visitor. Human Geography, 24, 97-102.

Chen, Y. Y. (2006). Empirical Study on Visitor Perception and Satisfaction-Case Study of Tourism Destination of Kaifeng. Journal of Henan University, 36, 62-66.

Cohen, E. (1988). Authenticity and Commoditization in Tourism. Annals of Tourism Research, 15, 371-386. https://doi.org/10.1016/0160-7383(88)90028-X

Feng, S. H., \& Sha, R. (2007). Study on Evaluation Model of "Authenticity and Satisfaction" from Visitors in Ancient Village Tourism. Human Geography, 22, 85-89.

Gao, F. (2008). Study on Cultural Commercialization and Authenticity in Minority Tourism Development-Case Study of Dynamic Yunnan. Journal of Baoshan Normal College, 27, 53-56.

Goulding, C. (2000). The Commodification of the Past, Postmodern Pastiche, and the Search for Authentic Experiences at Contemporary Heritage Attractions. European Journal of Marketing, 34, 835-853. https://doi.org/10.1108/03090560010331298

Hu, J. L. (2010). Study on Visitor's Perception on Industrial Heritage Authenticity in Shanghai. Shanghai: Shanghai Normal University.

Huang, Y. L., \& Huang, Z. F. (2008). Perception Structural Model and Application of Rural Visitors-Case Study of South-West Minority Region. Geographic Research, 27, 1455-1465.

Hughes, G. (1995). Authenticity in Tourism. Annals of Tourism Research, 22, 781-803.

Li, Y. L., Chen, Y. S., \& Zhang, L. (2007). Cultural Heritage Tourism Study in the Perspective of Visitor Perception and Preference-Case Study on Peing Yao Town. Reform and Strategy, 12, 123-126.

Liu, R., Su, W. C., \& Teng, J. Z. (2005). On Rural Eco-Tourism Development in Guizhou. Eco-Economy, 6, 86-89.

Luo, Y. J., Wu, C. C., \& Deng, J. Y. (2007). Comparative Study on Affecting Perception of Visitor's Entertainment Based on Leisure Motive-Case Study of Zhangjiajie National Forest Park. Issues of Forestry Economics, 27, 8-61.

Ma, X. J. (2006). Study on Authenticity of Foreign National Cultural Heritages. Study on Minority of Guangxi, 3, 185-190.

Shi, C. Y., \& Liu, Z. H. (2009). Study on Visitor Satisfaction Based on Pure Perception Model. Tourism Tribune, 4, 51-55.

Shi, C. Y., Zhang, J., \& You, H. H. (2008). Structural Equation Model of Tourism Destination Competitiveness in the Perspective of Visitor Perception. Geographical Research, 27, 703-714.

Tian, M., \& Bao, J. (2005). Study on Authenticity of Performance from Visitors-Case Study of Dance in Xishuangbanna. Journal of Guilin Tourism University, 16, 12-19.

Tomaz, K., \& Vesna, Z. (2009). A Consumer-Based Model of Authenticity. Tourism Management, 1, 1-13.

Tong, Q., \& Yang, R. (2009). Visitor Satisfaction Evaluation of Dongda Spring Resort of Xian. Anhui Agricultural Science, 27, 13421-13423.

Wang, W. (2006). An Introduction to Intangible Cultural Heritage. The Press of Culture and Art.

Wang, X. X., \& Zhang, C. Z. (2007). Understanding Difference of Authenticity in Herit- 
age Tourism and Heritage Management. Tourism Science, 21, 13-16.

Yang, Y., \& Li, T. (2007). Study on Xian Rural Tourism Development in Perspective of Visitor Perspective Evaluation. Tourism Tribune, 22, 32-37.

Yeoman, I. S. Brass, D., \& Mcmahon-Beattie, U. (2007). Current Issue in Tourism: The Authentic Tourist. Tourism Management, 28, 1128-1138. https://doi.org/10.1016/j.tourman.2006.09.012

Zhang, Y. (2009). Empirical Study on the Influence of Visitor Shopping Experience on Purchase Willingness. Journal of Jiangxi University of Finance and Economic, 5, 98-102.

Zhou, Y., Wu, M., Zhou, Y., \& Zhu, Y. (2007). Study and Comparasim of Autenticity in Tourism. Tourism Tribune, 6, 42-47. 